Arq. Bras. Med. Vet. Zootec., v.68, n.6, p.1539-1547, 2016

\title{
Kinematic and spermatic recovery after selection by centrifugation in colloid solutions of ovine cryopreserved semen
}

\author{
[Cinética e recuperação espermática após seleção por centrifugação em soluções \\ coloidais de sêmen ovino criopreservado] \\ T.G. Bergstein ${ }^{1,2}$, L.C. Bicudo ${ }^{1}$, L. Rodello ${ }^{1}$, R.R. Weiss ${ }^{2}$, S.D. Bicudo ${ }^{1}$ \\ ${ }^{1}$ FMVZ - UNESP, Botucatu-SP \\ ${ }^{2}$ Programa de pós-graduação - Universidade Federal do Paraná - Curitiba, PR
}

\begin{abstract}
Frozen and thawed ovine semen undergo morphological and functional changes that prevent or decrease the efficiency of fertilization. Sperm selection methods seek to improve the quality and viability of the fertilizing materials. Four sperm selection methods were employed, using two silica colloidal solutions coated with silane (silica colloidal-silane) or by polyvinylpyrrolidone (silica colloidal-PVP), and varying the volume of colloidal solution. Sperm kinematic and sperm recovery were evaluated by means of CASA. The protocols using silica colloidal-silane showed higher total motility (TM), progressive motility (PM) and percentage of rapid sperm (\%RAP) compared to the methods employing silica colloidal-PVP and to the samples prior to sperm selection. The silica colloidal-PVP had greater sperm recovery compared to the silica colloidal-silane. Only the method using $4 \mathrm{~mL}$ of silica colloidal-PVP was not efficient in selecting samples with better quality compared to the samples analyzed prior to sperm selection. The methods using lower volumes of colloidal solution did not differ from those using higher volumes and the best results were shown by the method with $1 \mathrm{~mL}$ silica colloidal-silane. The results found in the study indicated greater efficiency of the silica colloidal-silane solution for sperm selection of thawed ovine semen when compared to selection using silica colloidal-PVP. The method using $1 \mathrm{~mL}$ of silica colloidal-silane was equally efficient to the method with higher volume, presenting itself as an alternative to process samples with lower sperm concentration.
\end{abstract}

Keywords: ovine, semen, silane, selection, colloidal silica

\section{RESUMO}

O sêmen ovino congelado e descongelado sofre alterações morfofuncionais que impossibilitam ou diminuem a eficiência na fecundação. Os métodos de seleção espermática visam melhorar a qualidade e a viabilidade do material fecundante. Foram utilizados quatro métodos de seleção espermática utilizando duas soluções de sílica coloidal revestida por silano (sílica coloidal-silano) ou por polivinilpirrolidona (sílica coloidal-PVP), variando o volume de solução coloidal. Foram testadas a cinética espermática no CASA e a recuperação espermática. Os protocolos utilizando sílica coloidal-silano apresentaram maior motilidade total (MT), motilidade progressiva (MP) e porcentagem de espermatozoides rápidos (\% RAP) quando comparados aos métodos utilizando a sílica coloidal-PVP e às amostras antes da seleção espermática. A sílica coloidal-PVP teve maior recuperação espermática quando comparada à sílica coloidal-silano. Somente o método utilizando $4 m L$ de sílica coloidal-PVP não foi eficiente na seleção de amostras com melhor qualidade quando comparado às amostras analisadas antes da seleção espermática. Os métodos utilizando menores volumes de solução coloidal não diferiram dos métodos de maior volume, sendo a sílica coloidal-silano com $1 \mathrm{~mL}$ o método que apresentou os melhores resultados. Como conclusão, os resultados encontrados no trabalho apontaram a maior eficiência da sílica coloidal-silano em selecionar sêmen ovino congelado e descongelado quando comparado à seleção em sílica coloidal-PVP. O método utilizando $1 \mathrm{~mL}$ de sílica coloidal-silano foi igualmente eficiente ao método com maior volume, sendo uma alternativa para processar amostras com baixa concentração espermática.

Palavras-chave: ovino, sêmen, silano, seleção, silica coloidal

Recebido em 4 de dezembro de 2015

Aceito em 4 de abril de 2016

E-mail: tacia@alamos.com.br 


\section{INTRODUCTION}

The ovine ejaculate is composed of a heterogeneous population of spermatic cells (Alvarez et al., 2010) that vary according to motility, morphology, membrane integrity and viability. Cryopreservation of semen causes injuries to spermatic cells, which can lead to an increase in the population of spermatozoa unable to fertilize the oocyte (Jimenez-Rabadan et al., 2012). There are several methods of sperm selection that significantly improve the quality of semen (Samardzija et al., 2006). These methods separate the sperm from the seminal plasma and diluents and select the motile cells or cells with normal morphology. The application of these techniques is routine in in vitro fertilization (Mehmood et al., 2009; Alvarez et al., 2010). However, these techniques can also have important applications in ovine artificial insemination programs (Marti et al., 2006). Sperm selection through centrifugation in colloidal solutions is based on the fact that sperm cells with progressive motility can move through macromolecules faster than immobile or low motile sperm (Rho et al., 2001). A widely used method in sperm selection is centrifugation in colloid solutions in continuous (Single Layer Centrifugation-SLC) or discontinuous gradients (Discontinuous Layer Centrifugation - DLC).

DLC is composed of two solutions with different densities. Some examples are Percoll $^{\circledR}$ (Mehmood et al., 2009), Puresperm ${ }^{\circledR}$ (Dorado et al., 2013), and Bovipure ${ }^{\circledR}$ (Samardzija et al., 2005). Percoll ${ }^{\circledR}$ is composed of silica colloidal particles (diameter of $15-30 \mathrm{~nm}$ ) coated with nonhydrolysable polyvinylpyrrolidone (PVP) (Samardzija et al., 2005). Some batches of Percoll ${ }^{\circledR}$ can differ among themselves and certain endotoxic effects are found in the sperm cell, justifying the ban on Percoll ${ }^{\circledR}$ for use in assisted human reproduction (Makkar et al., 1999; Mendes et al., 2003).

SLC has only one density within the entire centrifugation column, and some examples are Androcoll- $E^{\circledR}$ and Ovipure ${ }^{\circledR}$. The SLC has some advantages when compared to DLC. Among them are the specificity of the formulations, homogeneity of batches, ease of gradient formation and mobility of volumes, depending on the sample to be selected (Sjunnesson et al., 2013). Ovipure ${ }^{\circledR}$ is an iso-osmotic solution with silica colloid particles coated with silane and has low toxicity for the sperm. Ovipure ${ }^{\circledR}$ was developed exclusively for use in ovine, but does not differ substantially from other products from the same company, such as those specific for bovines (Bovipure ${ }^{\circledR}$ ), equines (Equipure ${ }^{\circledR}$ ) and humans (PureSperm ${ }^{\circledR}$ ).

Studies with bovines (Mendes et al., 2003; Samardzija et al., 2005; Thys et al., 2009), equines (Gutierrez-Cepeda et al., 2011; Morrel et al, 2013; Rodríguez-Villamil et al, 2012), swine (Martinez-Alborcia et al., 2012; Bucci et al., 2013; Sjunnesson et al., 2013), dogs (Hishinuma e Sekine, 2004), goats (Jimenez-Rabadan et al.,2012) and humans (Perez et al., 1997) reported an increase in the quality and viability of semen post selection in SLC or DLC. However, there are no studies that compare these two sperm selection methods in ovine.

The aim of this study was to compare four methods of sperm selection varying the volume of two silica colloid solutions coated with silane (Ovipure $^{\circledR}$ ) or PVP $\left(\right.$ Percoll $^{\circledR}$ ) and its effects on the kinematic analysis and spermatic recovery of ovine cryopreserved semen.

\section{MATERIAL AND METHODS}

This study was approved by the Ethics Committee on Animal Use from the Institution FMVZ-UNESP (CEUA-FMVZ-UNESP 270/2011).

Triplicates of frozen and thawed semen were used from ten Dorper sheep. The average sperm per dose was $149 \pm 9.41 \times 106$, packaged in $0.25 \mathrm{ml}$ straws, and diluted in an extender containing glycine, 5\% egg yolk and milk (GGL5\%) (Rodello et al., 2011). The doses were frozen in automatic equipment (TK $3000^{\circledR}$, TK Congelações, Brasil) with standard curve for freezing ovine semen "S2P3". Thawing was carried out by submerging the straws in a water bath at $40^{\circ} \mathrm{C}$ for 20 seconds. Immediately after thawing, the exact observation of semen volume was done through direct observation of the semen column in the palette with scale units equivalent to $10 \mu \mathrm{L}$. The content of the palette was poured into a conic-bottomed tube, previously heated to $37^{\circ} \mathrm{C}$. Aliquotes of this sample were taken for the spermatic analyses. 
Ovipure ${ }^{\circledR}$ was donated by the company Nidacon Laboratories AB, Göthenborg, Sweden. The Percoll $^{\circledR}$ gradient used in the experiment was produced by the company Nutricell Nutrientes Celulares LTDA, Campinas, Brazil. The concentrations of Percoll $^{\circledR}$ used were $90 \%$ and $45 \%$. The extracts of the glycine, yolk and milk extender (EGGL) were obtained through the centrifugation of the GGL5\% extender without glycerol (Rodello et al., 2011) at $10000 \mathrm{~g}$ for 15 minutes and temperature of $4^{\circ} \mathrm{C}$, adapted from the method of Falleiros et al. (2013). EGGL5\% was used to clarify the samples in the sperm kinematic analysis.

Two protocols were prepared using silica colloidal-silane (Ovipure ${ }^{\circledR}$ - Nidacon Laboratories AB, Göthenborg, Sweden). The O4 protocol followed the manufacturer's recommendations, while the $\mathrm{O} 1$ protocol was reduced in volume in order to potentiate the use of the product.

Preparation for $\mathrm{O} 4$ centrifugation was performed in a Falcon ${ }^{\circledR}(\mathrm{BD}-$ Becton Dickison, San José, CA, USA) tube $(15 \mathrm{~mL}$ capacity) with $4 \mathrm{~mL}$ of silica colloidal-silane solution. For the second protocol, O1, an Eppendorf ${ }^{\circledR}$ (Eppendorf AG Hamburg, ALE) tube (1.5mL capacity) with $1 \mathrm{~mL}$ of the same solution was used. In both protocols, at the top of the columns, $250 \mu \mathrm{L}$ of thawed semen were carefully poured. The tubes were centrifuged at a fixed temperature of $25^{\circ} \mathrm{C}$, for 20 minutes, at $300 \mathrm{~g}$ intensity. After centrifugation, the supernatant was removed, remaining $750 \mu \mathrm{L}$ of the decanted pellet for $\mathrm{O} 4$ and $200 \mu \mathrm{L}$ of the decanted pellet in $\mathrm{O} 1$. This pellet was resuspended in $4250 \mu \mathrm{L}(\mathrm{O} 4)$ and $1050 \mu \mathrm{L}(\mathrm{O} 1)$ of EGGL and subjected to centrifugation for 10 minutes at an intensity of $500 \mathrm{~g}$ and temperature of $25^{\circ} \mathrm{C}$. After centrifugation, the supernatant was carefully removed, remaining the pellet of $300 \mu \mathrm{L}(\mathrm{O} 4)$ and $200 \mu \mathrm{L}(\mathrm{O} 1)$, which was homogenized and subjected to in vitro analyses.

The centrifugation gradient $\mathrm{P} 4$ was prepared in a $15 \mathrm{~mL}$ Falcon ${ }^{\circledR}$ tube. At the bottom of the tube, $2 \mathrm{~mL}$ of Percoll ${ }^{\circledR} 90 \%$ were poured, followed by careful dispensation of $2 \mathrm{~mL}$ of Percoll $^{\circledR} 45 \%$, thereby setting the gradient for centrifugation. For the P1 method, $1.5 \mathrm{~mL}$ Eppendorf ${ }^{B}$ tubes were used. First, $0.5 \mathrm{~mL}$ of $90 \%$ Percoll $^{\circledR}$ was pipetted into the bottom of the tube, followed by $0.5 \mathrm{~mL}$ of $45 \%$ Percoll $^{\circledR}$, thus setting the gradient for centrifugation. The volume of frozen and thawed semen of $250 \mu \mathrm{L}$ with average spermatic count of $100 \times 10^{6}$ spermatozoa was carefully placed on the column of silica colloidal-PVP in both methods. The tubes were centrifuged for 15 minutes at $900 \mathrm{~g}$ intensity and a fixed temperature of $25^{\circ} \mathrm{C}$. Next, the supernatant was removed, remaining $750 \mu \mathrm{L}$ in $\mathrm{P} 4$ and $200 \mu \mathrm{L}$ in $\mathrm{P} 1$ of the decanted pellet. This pellet was re-suspended in $4250 \mu \mathrm{L}(\mathrm{P} 4)$ and $1050 \mu \mathrm{L}(\mathrm{P} 1)$ of EGGL and subjected to centrifugation for five minutes at $300 \mathrm{~g}$ intensity and temperature of $25^{\circ} \mathrm{C}$. Next, the supernatant was carefully discarded and the remaining pellet of $300 \mu \mathrm{L}$ in $\mathrm{P} 4$ and $200 \mu \mathrm{L}$ in P1 were homogenized and subjected to in vitro analyses.

The in vitro analysis of the semen was carried out in two moments: immediately after thawing, before selection $(\mathrm{O} 4 \mathrm{~b}, \mathrm{O} 1 \mathrm{~b}, \mathrm{P} 4 \mathrm{~b}, \mathrm{P} 1 \mathrm{~b})$ and after selection (O4a, O1a, P4a, P1a).

For evaluation of the sperm kinematic, $10 \mu \mathrm{L}$ of frozen and thawed sperm was previously diluted in $300 \mu \mathrm{L}$ of EGGL and maintained heated at $37^{\circ} \mathrm{C}$. Approximately $6 \mu \mathrm{L}$ of diluted semen was deposited into the Makler chamber (Makler Counting Chamber - Selfi-Medical, Haifa, Israel) and submitted to Computer Assisted Sperm Analysis (CASA) in the Hamilton Thorn Motility Analyzer - HTMA -IVOS 12 equipment (Hamilton Research - Beverly, MA, USA). One frame of the chamber was chosen by the examiner and two other frames were randomly chosen by the equipment and analyzed for total motility (TM, \%), progressive motility (PM,\%), velocity according to the smoothed path (VAP, $\mu \mathrm{m} / \mathrm{s}$ ), velocity according to the straight path (VSL, m/s), velocity according to the actual path $(\mathrm{VCL}, \mu \mathrm{m} / \mathrm{s})$, amplitude of lateral head displacement (ALH, $\mu \mathrm{m})$, head beat-cross frequency $(\mathrm{BCF}, \mathrm{Hz})$, straightness (STR, \%), linearity index (LIN, \%) and percentage of rapid sperm (RAP, \%). The setup used was based on the manufacturer's recommendations, which were obtained through the equipment manual (HAMILTON THORNE SETUP FOR IVOS12.3). The cell size was of 5 pixels, cell intensity of 55 , VAP $75 \mu / \mathrm{s}$, STR $80 \%$, VAP cutoff $21.9 \mu / \mathrm{s}$, VSL cutoff $6.0 \mu / \mathrm{s}$, minimum static intensity gates 0.25 , maximum static intensity gates 1.5 , minimum static size gates 0.6 and maximum static size gates 8.0, minimum elongation gates 0 and maximum elongation gates 95. Magnification calibration was of 1.95 , video source frequency of $60 \mathrm{~Hz}, 2400$ light 
intensity, low photometer 73 and high photometer 125 .

Sperm concentration was determined by cell counting with a Neubauer Chamber. Immediately after thawing, a 1:400 dilution was used and after centrifugation a 1:20 dilution was used, due to lower concentration. Recovery of spermatic cells after selection in silica colloidal-silane and silica colloidal-PVP extenders was estimated in two ways. In the first, total recovery of spermatic cells (REC) was calculated from the formula:

$\mathrm{REC}=($ Total spermatozoa after centrifugation $) /$ (total spermatozoa before centrifugation) $* 100$

In the second, recovery considering total motility (RECMT) was calculated from the formula:

RECMT = (total spermatozoa after centrifugation*total motility after centrifugation) / (total spermatozoa before centrifugation*total motility before centrifugation) $* 100$

The analyses of the samples were not paired. Data were analyzed in a randomized block design with eight treatments $(\mathrm{O} 4 \mathrm{~b}$; $\mathrm{P} 4 \mathrm{~b}$; O $1 \mathrm{~b}$; P1b; O4a; P4a; O1a; P1a) and ten blocks (rams). The data used in the analyses were the average of the values obtained from the triplicates of each ram. The variables showed normal distribution and variance homogeneity according to the Kolmorogov-Smirnov method. ANOVA followed by the Tukey test were implemented in the GraphPad Prism ${ }^{\circledR}$ software, version 5.03 for Windows. The level of significance was $\mathrm{P}>0.05$.

\section{RESULTS}

The TM and PM results are described in Table 1. Both total motility results before centrifugation in silica colloidal-silane and silica colloidal-PVP in the protocols with $4 \mathrm{~mL}-\mathrm{O} 4 \mathrm{~b}(27.0 \pm 3.1 \%)$, $\mathrm{P} 4 \mathrm{~b}(27.0 \pm 2.3 \%), 1 \mathrm{~mL} \mathrm{O} 1 \mathrm{a}(24.3 \pm 1.9 \%)$ and P1b (24.7 $\pm 2.3 \%)$ - did not differ among themselves $(\mathrm{P}>0.05)$. After sperm selection, TM was higher $(\mathrm{P}<0.05)$ in both centrifugation protocols using silica colloidal-silane (O4a: 62.0 $\pm 4.1 \%$; Ola: $64.6 \pm 3.8 \%$ ), and there was no difference between the methods $(\mathrm{O} 4 \mathrm{a}=\mathrm{O} 1 \mathrm{a})$.

In the protocol using silica colloidal-PVP $4 \mathrm{~mL}$ (P4a) there was no difference $(\mathrm{P}>0.05)$ in $\mathrm{TM}$ compared to that before centrifugation ( $\mathrm{P} 4 \mathrm{~b}: 27.0$ $\pm 2.3 \%$; P4a: $30.0 \pm 3.6 \%$ ). However, TM after centrifugation in silica-colloidal PVP $1 \mathrm{~mL}$ column (P1a: $45.9 \pm 4.3 \%)$ was greater $(\mathrm{P}<0.05)$ when compared to the analyses before selection (P1b: $24.7 \pm 2.3 \%$ ), but lower than the methods O4a and O1a (O4a: $62.0 \pm 4.1 \%$; O1a: $64.6 \pm$ $3.8 \%)$.

Table 1. Averages \pm standard error of total motility (TM) and progressive motility (PM) in the treatments before and after centrifugation in $4 \mathrm{~mL}$ colloidal silica coated with silane or polyvinylpyrrolidone and before or after centrifugation in $1 \mathrm{~mL}$ volume of colloidal silica coated with silane or polyvinylpyrrolidone (PVP), of cryopreserved ovine semen

\begin{tabular}{|c|c|c|c|c|c|c|c|c|}
\hline Variables & \multicolumn{3}{|c|}{$4 \mathrm{~mL}$ colloidal silica } & & \multicolumn{4}{|c|}{$1 \mathrm{~mL}$ colloidal silica } \\
\hline TM (\%) & $27.0 \pm 3.1 \mathrm{c}$ & $62.0 \pm 4.1 \mathrm{a}$ & $27.0 \pm 2.3 \mathrm{c}$ & $30.0 \pm 3.6 \mathrm{c}$ & $24.3 \pm 1.9 \mathrm{c}$ & $64.6 \pm 3.8 \mathrm{a}$ & $24.7 \pm 2.3 \mathrm{c}$ & $45.9 \pm 4.3 b$ \\
\hline PM (\%) & $18.0 \pm 2.6 \mathrm{~b}$ & $42.0 \pm 4.0 \mathrm{a}$ & $15.0 \pm 1.9 \mathrm{~b}$ & $18.0 \pm 2.9 \mathrm{~b}$ & $15.0 \pm 1.6 \mathrm{~b}$ & $46.8 \pm 3.0 \mathrm{a}$ & $15.4 \pm 1.6 \mathrm{~b}$ & $25.1 \pm 2.9 \mathrm{~b}$ \\
\hline
\end{tabular}

Averages followed by different lower case letters in the same line $(\mathrm{P}<0.05)$ differ among themselves by the Tukey test.

Sperm kinematic results are described in Table 2. There were no differences $(\mathrm{P}>0.05)$ between treatments before and after selection in VAP, VCL and ALH. VSL was lower in P1a when compared to the sample before selection (P1b: $108.6 \pm 3.1 \mu \mathrm{m} / \mathrm{s} ; \mathrm{P} 1 \mathrm{a}: 88.9 \pm 3.8 \mu \mathrm{m} / \mathrm{s})$. BCF was lower $(\mathrm{P}<0.05)$ in $\mathrm{P} 1 \mathrm{a}$ and $\mathrm{P} 4 \mathrm{a}(\mathrm{P} 1 \mathrm{a}: 37.6 \pm$ $0.6 \mathrm{~Hz}$; P4a: $36.3 \pm 0.7 \mathrm{~Hz})$, which did not differ among themselves $(\mathrm{P}<0.05)$ when compared to the samples before selection $(\mathrm{P} 1 \mathrm{~b}: 41.7 \pm 0.7 \mathrm{~Hz}$; P4b: $44.1 \pm 1 \mathrm{~Hz}$ ) and to the treatments using silica colloidal-silane (O1a: $41 \pm 1 \mathrm{~Hz}$; O4a: 41.3 $\pm 0.8 \mathrm{~Hz})$.

The \%RAP was higher $(\mathrm{P}<0.05)$ in $\mathrm{O} 1 \mathrm{a}(52.3 \pm$ $3.3 \%)$ and $\mathrm{O} 4 \mathrm{a}(49.1 \pm 4.2 \%)$ compared to the 
samples before selection and to the methods using silica colloidal-PVP. In P1a $(31 \pm 3.4 \%)$ there was an increase $(\mathrm{P}<0.05)$ in $\% \mathrm{RAP}$ when compared to that of P1b $(17.5 \pm 1.9 \%)$, but did not differ $(\mathrm{P}>0.05)$ from $\mathrm{P} 4 \mathrm{a}(21.3 \pm 3.1 \%)$ and from $\mathrm{P} 4 \mathrm{~b}(20.1 \pm 2.2 \%)$.

Table 2. Averages \pm standard error of sperm kinematic analyzed in the computerized system (CASA) of the treatments before and after centrifugation in $4 \mathrm{~mL}$ of colloidal silica coated with silane or polyvinylpyrrolidone and before or after centrifugation in $1 \mathrm{~mL}$ of colloidal silica coated with silane or polyvinylpyrrolidone, of cryopreserved ovine semen

\begin{tabular}{|c|c|c|c|c|c|c|c|c|}
\hline \multirow[b]{2}{*}{ Variables } & \multicolumn{2}{|l|}{ Silane } & \multicolumn{2}{|l|}{ PVP } & \multicolumn{2}{|l|}{ Silane } & \multicolumn{2}{|l|}{ PVP } \\
\hline & $\begin{array}{l}\text { Before } \\
\text { (O4b) }\end{array}$ & $\begin{array}{l}\text { After } \\
(\mathrm{O} 4 \mathrm{a})\end{array}$ & $\begin{array}{l}\text { Before } \\
\text { (P4b) }\end{array}$ & $\begin{array}{l}\text { After } \\
\text { (P4a) }\end{array}$ & $\begin{array}{l}\text { Before } \\
\text { (O1b) }\end{array}$ & $\begin{array}{l}\text { After } \\
(\mathrm{Ola})\end{array}$ & $\begin{array}{l}\text { Before } \\
\text { (P1b) }\end{array}$ & $\begin{array}{l}\text { After } \\
\text { (P1a) }\end{array}$ \\
\hline $\begin{array}{l}\text { VAP } \\
(\mu \mathrm{m} / \mathrm{s})\end{array}$ & $112.4 \pm 4.6^{\mathrm{a}}$ & $119 \pm 4.2^{\mathrm{a}}$ & $120.5 \pm 4^{\mathrm{a}}$ & $103.7 \pm 3.6^{\mathrm{a}}$ & $114.6 \pm 4.1^{\mathrm{a}}$ & $110.1 \pm 4.2^{\mathrm{a}}$ & $119.4 \pm 2.9^{\mathrm{a}}$ & $105.5 \pm 3.6^{\mathrm{a}}$ \\
\hline $\operatorname{VSL}(\mu \mathrm{m} / \mathrm{s})$ & $100.2 \pm 4.5^{\mathrm{ab}}$ & $105.6 \pm 4.4^{\mathrm{ab}}$ & $109.1 \pm 4.2^{\mathrm{a}}$ & $92 \pm 3.8^{\mathrm{ab}}$ & $100.7 \pm 4.2^{\mathrm{ab}}$ & $98.46 \pm 4.2^{\mathrm{ab}}$ & $108.6 \pm 3.1^{\mathrm{a}}$ & $88.99 \pm 3.8^{b}$ \\
\hline $\begin{array}{l}\text { VCL } \\
(\mu \mathrm{m} / \mathrm{s})\end{array}$ & $170.6 \pm 6.7^{\mathrm{ab}}$ & $176.5 \pm 5.5^{\mathrm{ab}}$ & $182.4 \pm 5.5^{\mathrm{ab}}$ & $155 \pm 5.1^{\mathrm{b}}$ & $171.8 \pm 11.4^{\mathrm{ab}}$ & $160.2 \pm 5.0^{\mathrm{ab}}$ & $183.4 \pm 4.7^{\mathrm{a}}$ & $162 \pm 4.9^{\mathrm{ab}}$ \\
\hline ALH $(\mu \mathrm{m})$ & $5.47 \pm 0.2^{\mathrm{a}}$ & $5.46 \pm 0.2^{\mathrm{a}}$ & $7.31 \pm 1.6^{\mathrm{a}}$ & $5.59 \pm 0.2^{\mathrm{a}}$ & $4.95 \pm 0.2^{\mathrm{a}}$ & $5.08 \pm 0.1^{\mathrm{a}}$ & $5.7 \pm 0.1^{\mathrm{a}}$ & $5.7 \pm 0.1^{\mathrm{a}}$ \\
\hline $\mathrm{BCF}(\mathrm{Hz})$ & $44 \pm 0.9^{\mathrm{a}}$ & $41.3 \pm 0.8^{\mathrm{a}}$ & $44.1 \pm 1^{\mathrm{a}}$ & $36.3 \pm 0.7^{\mathrm{b}}$ & $41.8 \pm 0.6^{\mathrm{a}}$ & $41 \pm 1^{\mathrm{a}}$ & $41.7 \pm 0.7^{\mathrm{a}}$ & $37.6 \pm 0.6^{\mathrm{b}}$ \\
\hline STR $(\%)$ & $84.5 \pm 0.8^{\mathrm{b}}$ & $87.9 \pm 0.9^{\mathrm{a}}$ & $82 \pm 2^{\mathrm{b}}$ & $84.4 \pm 1.2^{\mathrm{b}}$ & $83.4 \pm 0.9^{\mathrm{b}}$ & $89 \pm 0.8^{\mathrm{a}}$ & $85 \pm 0.8^{\mathrm{b}}$ & $80.7 \pm 1^{\mathrm{b}}$ \\
\hline LIN (\%) & $57.7 \pm 1.3^{\mathrm{ab}}$ & $58.3 \pm 1.5^{\mathrm{ab}}$ & $60.9 \pm 1.3^{\mathrm{a}}$ & $59.1 \pm 1.3^{\mathrm{ab}}$ & $59.2 \pm 1.2^{\mathrm{ab}}$ & $60.2 \pm 1.3^{\mathrm{ab}}$ & $60.8 \pm 1.2^{\mathrm{a}}$ & $54.9 \pm 1.2^{\mathrm{b}}$ \\
\hline$\% \operatorname{Rap}(\%)$ & $22 \pm 2.8^{\mathrm{bc}}$ & $49.1 \pm 4.2^{\mathrm{a}}$ & $20.1 \pm 2.2^{\mathrm{bc}}$ & $21.3 \pm 3.1^{\mathrm{b}}$ & $17.3 \pm 1.8^{\mathrm{c}}$ & $52.3 \pm 3.3^{\mathrm{a}}$ & $17.5 \pm 1.9^{\mathrm{c}}$ & $31 \pm 3.4^{\mathrm{b}}$ \\
\hline
\end{tabular}

Averages followed by different lower case letters in the same line $(\mathrm{P}<0.05)$ differ among themselves by the Tukey test.

VAP - Average path velocity; VSL - Straight-line velocity; VCL - Curvilinear velocity; ALH - Amplitude of lateral head displacement; BCF - Beat cross frequency; STR - Straightness; LIN - Linearity; \%Rap - percentage of rapid sperm; mL-milliliters

The number of spermatozoa $\left(\mathrm{N}^{\mathrm{o}} \mathrm{sptz}\right)$ (Tab. 3) before centrifugation differed between the protocols with $4 \mathrm{~mL}$ and $1 \mathrm{~mL}(\mathrm{O} 4 \mathrm{~b}, \mathrm{P} 4 \mathrm{~b}$ and $\mathrm{O} 1 \mathrm{~b}, \mathrm{P} 1 \mathrm{~b})$, but did not differ within the same method $(\mathrm{O} 4 \mathrm{~b} \cong \mathrm{P} 4 \mathrm{~b}$ and $\mathrm{O} 1 \mathrm{~b} \cong \mathrm{P} 1 \mathrm{~b})$. In all methods, the $\mathrm{N}^{\circ}$ sptz was lower $(\mathrm{P}<0.05)$ after centrifugation when compared to the samples before selection. There was no significant difference in the $\mathrm{N}^{\circ}$ sptz after centrifugation among the protocols (O4a, P4a, O1a, P1a).

Table 3. Average \pm standard error of the number of spermatozoa, total motility (TM), recovery with or without considering TM of the treatments before and after centrifugation in $4 \mathrm{~mL}$ of coloidal silica coated with silane or polyvinylpyrrolidone and before or after centrifugation in volumes of $1 \mathrm{~mL}$ of colloidal silica coated with silane or polyvinylpyrrolidone of cryopreserved ovine semen

\begin{tabular}{|c|c|c|c|c|c|c|c|c|}
\hline \multirow{2}{*}{ Variables } & \multicolumn{2}{|l|}{ Silane } & \multicolumn{2}{|l|}{ PVP } & \multicolumn{2}{|l|}{ Silane } & \multicolumn{2}{|l|}{ PVP } \\
\hline & $\begin{array}{l}\text { Before } \\
\text { (O4b) }\end{array}$ & $\begin{array}{l}\text { After } \\
\text { (O4a) }\end{array}$ & $\begin{array}{l}\text { Before } \\
\text { (P4b) }\end{array}$ & $\begin{array}{l}\text { After } \\
\text { (P4a) }\end{array}$ & $\begin{array}{l}\text { Before } \\
\text { (O1b) }\end{array}$ & $\begin{array}{l}\text { After } \\
\text { (O1a) }\end{array}$ & $\begin{array}{l}\text { Before } \\
\text { (P1b) }\end{array}$ & $\begin{array}{l}\text { After } \\
\text { (P1a) }\end{array}$ \\
\hline $\begin{array}{l}\mathrm{N}^{\circ} \mathrm{sptz} \\
\left(\mathrm{x} 10^{6} \mathrm{sptz}\right)\end{array}$ & $132 \pm 7.8^{b}$ & $9.3 \pm 0.9^{c}$ & $134 \pm 10.4^{b}$ & $22.1 \pm 3.5^{\mathrm{c}}$ & $166 \pm 9.8^{\mathrm{a}}$ & $6.5 \pm 0.6^{\mathrm{c}}$ & $167 \pm 9.6^{\mathrm{a}}$ & $23.5 \pm 2.5^{\mathrm{c}}$ \\
\hline $\operatorname{Rec}(\%)$ & - & $9.1 \pm 1.5^{\mathrm{abA}}$ & - & $16.2 \pm 2.1^{\mathrm{a}}$ & - & $4.09 \pm 0.3^{\mathrm{bA}}$ & - & $14.5 \pm 1.4^{\mathrm{a}}$ \\
\hline $\begin{array}{l}\text { RecMT } \\
(\%)\end{array}$ & - & $22.4 \pm 3.7^{\mathrm{bB}}$ & - & $17.9 \pm 2.8^{b}$ & - & $11.8 \pm 1.2^{\mathrm{bB}}$ & - & $34.6 \pm 8.9^{\mathrm{a}}$ \\
\hline
\end{tabular}

Averages followed by different lower case letters in the same line $(\mathrm{P}<0.05)$ differ among themselves by the Tukey test. Averages followed by different upper case letters differ among themselves in the column by the Tukey test $(\mathrm{P}<0.05)$.

$\mathrm{N}^{\mathrm{o}} \mathrm{Stpz}$ - number of spermatozoa; MT- total motility; Rec - recovery; RecMT - recovery considering total motility; Sptz - spermatozoa 
Sperm recovery (REC) was the same $(\mathrm{P}>0.05)$ among protocols within the same product $(\mathrm{O} 4 \mathrm{a}$ : $9.1 \pm 1.5 \% \cong 01 \mathrm{a}: 4.1 \pm 0.3 \%$ and $\mathrm{P} 4 \mathrm{a}: 16.2 \pm$ $2.1 \% \cong \mathrm{P} 1 \mathrm{a}: 14.5 \pm 1.4 \%$ ), but differed among the products used.

REC was higher $(\mathrm{P}<0.05)$ for protocols using silica colloidal-PVP (P4a and P1a). O4a did not differ from the methods using silica colloidalPVP. In the O1 method, REC was lower but did not differ from $\mathrm{O} 4 \mathrm{a}$.

Recovery considering total motility (RECTM) did not differ $(\mathrm{P}>0.05)$ among $\mathrm{O} 4 \mathrm{a}(22.4 \pm 3.7 \%)$, $\mathrm{P} 4 \mathrm{a}(17.9 \pm 2.8 \%)$ and O1a $(11.8 \pm 1.2 \%)$. RECTM was higher $(\mathrm{P}<0.05)$ in $\mathrm{P} 1 \mathrm{a}(34.6 \pm 8.9 \%)$.

\section{DISCUSSION}

TM and PM have a positive correlation with sperm viability (Maia et al., 2009) and can interfere in the fertility of semen because these parameters are closely related to the capacity of the sperm cell to achieve the fecundation site (Dorado et al., 2011). Significant improvements in the TM, PM and \%RAP of the samples after selection in silica colloidal-silane were found. In these parameters, the protocols using silica colloidal-silane (O4a and O1a) surpassed the protocols of silica colloidal-PVP selection. Similar results were reported in other studies conducted with bovines (Mendes et al., 2003; Samardzija et al., 2005; Thys et al., 2009), humans (Makkar et al., 1999) and equines (Rodríguez-Villamil et al., 2012), who compared selection methods employing silica colloidalsilane and silica colloidal-PVP. There was no significant difference in TM and PM between the two protocols using silica colloidal-silane $(\mathrm{O} 4 \mathrm{a}$ and O1a). Furthermore, the reduction in the volume of the colloidal silica coated with silane solution was found to be efficient for sperm selection considering these parameters.

Only the P1a protocol showed improvement in TM when compared to protocol P1b. This result is consistent with those of Machado et al. (2009), who reduced the volume of Percoll ${ }^{\circledR}$ from the traditional $4 \mathrm{~mL}$ to $800 \mathrm{uL}$. In contrast to other authors (Samardzija et al., 2005; Machado et al., 2009; Mehmood et al., 2009; Alvarez et al., 2010), the present study did not report significant increase in TM and PM in the silica colloidalPVP protocol using $4 \mathrm{~mL}(\mathrm{P} 4)$ when compared to the samples before selection. These results can vary according to the concentration of colloidal silica solutions, gradient preparation (Thys et al., 2009), variations in the intensity of the $g$ force and centrifugation time (Gil et al., 2000; Thys et al., 2009), variation of washing solutions after sperm selection, quality of sample before centrifugation (Martinez-Alborcia et al., 2013), among other reasons.

Sperm kinematic parameters were close to those found in other experiments that evaluated frozen and thawed ovine semen with the same setup (Maia et al., 2009; Maia et al., 2010; Rodello et al., 2011; Sirchele et al., 2011).

P1a had the lowest LIN among all other methods and differed from P1b. STR differed from the analyzed samples before selection when compared to $\mathrm{P} 4 \mathrm{a}, \mathrm{O} 1 \mathrm{~b}$ and O4a. Similar results were found by Gutierrez Cepeda et al. (2011), who observed an increase in STR after sperm selection of equine semen in silica colloidalsilane, but were different from those of Thys et al. (2009), who found an increase in the LIN of bovine semen selected in silica colloidal-PVP.

The colloidal silica coated with PVP was used in centrifugation protocols with the aim of selecting and capacitating the semen for IVF. Mortimer and Maxwell (1999) standardized the identification of hyper-activated cells in ovine ejaculates based on sperm kinematic VCL $>250.0 \mu \mathrm{m}$ and VSL $\leq 100.0 \mu \mathrm{me}, \mathrm{LIN} \leq$ $30 \%$ and ALHmax $>9.0 \mu \mathrm{m}$. In this experiment, the average of the methods did not fit the standardization suggested by Mortimer and Maxwell (1999), indicating that there was no hyper-activation post sperm selection in neither of the two colloid solutions used.

Sperm concentration decreased after selection by centrifugation in the four methods used. This result was already expected considering that the selection separates spermatic cells that for some reason were not capable of crossing the gradient barrier.

Similar results were found in other studies using silica colloidal-PVP gradient in goats (Rho et al. 2001) and buffalos (Mehmood et al., 2009). Comparable results were also found in experiments with goats (Jimenez-Rabadan et al., 2012), equines (Anja et al., 2013) and dogs 
(Dorado et al., 2011), which employed speciespecific SLC methods.

REC was higher in P1a and P4a when the result is compared to the treatments with silica colloidal-silane. This result is consistent with other studies in which the recovery rate in sperm selection with silica colloidal-PVP was always superior to recovery of cells in silica colloidalsilane (Jimenes-Rabadan et al., 2012; Anja et al., 2013).

In RECTM, TM is taken into account and this parameter increased in all of the treatments, with significant difference when compared to the RECs. When considering TM, O4a and O1a were equivalent to $\mathrm{P} 4 \mathrm{a}$ and inferior to $\mathrm{P} 1 \mathrm{a}$, which showed a higher RECTM among the treatments. Similar results were found by Jimenez-Rabadan et al. (2012), who selected goat semen in a solution of silica coated with silane specific for bovines. The recovery rates can be altered by several factors, among them: quality of semen before centrifugation (Alvarez et al., 2010; Martinez-Alborcia et al., 2013), caution at the time of deposition of the semen sample at the top of the gradient selection column (Thys et al., 2009), TM increase after sperm selection, and time and intensity of centrifugation force (Carvajal et al., 2004). Martinez-Alborcia et al. (2013) hypothesized that non-functional spermatozoa saturate the interface between the semen and the colloid, obstructing the passage of functional spermatozoa.

Carvajal et al (2004) tested several swine semen centrifugation protocols and suggested that the intensity of the centrifugation force is more important than the centrifugation time in the sperm recovery rate. This fact would explain the higher recovery in the methods employing silica colloidal-PVP, considering that the intensity of the $g$ force was of 900 compared to 300 in the methods using silica colloidal-silane.

Studies with swine (Martinez-Alborcia et al., 2013; Sjunnesson et al., 2013) indicate that the use of selected sperm by SLC in IVF predisposes polysermy and can lead to embryonic loss due to the increase in TM and sperm viability. Sjunnesson et al. (2013) did not find significant differences when reducing the oocyte:spermatozoa ratio down to 1:300 in swine
IVF, but suggest that this would be an alternative to avoid polyspermy, besides from decreasing the incubation time. Considering this hypothesis, the low recovery after centrifugation in silica colloidal-silane can be compensated by the lower concentration of spermatozoa that should be used for IVF. As far as is known, there are no studies involving IVF and SLC in ovine. This kind of study is necessary in order to ascertain the optimal rate of oocytes:spermatozoa after selection by SLC, avoiding polyspermy.

The enrichment of the recovery is necessary in order to inhibit the loss of viable spermatozoa. For this, studies with the objective of improving centrifugation protocols, standardizing the concentration of processed samples, and altering the physical properties of the colloid would be necessary (Martinez-Alborcia et al., 2013).

In the TM, PM, kinematic and recovery parameters, the protocol with $1 \mathrm{~mL}$ of silica colloid-silane did not differ when compared to the traditional $4 \mathrm{~mL}$ method. Also, the method with $1 \mathrm{~mL}$ silica colloidal-PVP was superior to the method using $4 \mathrm{~mL}$.

\section{CONCLUSION}

The results obtained in this study indicate that silica colloidal-silane is more selective for the attainment of cryopreserved sperm samples with higher total motility, progressive motility and percentage of rapid sperm when compared to silica colloidal-PVP. On the other hand, silica colloidal-PVP shows higher recovery of spermatozoa and recovery considering total motility. Also, it is less selective for qualitative parameters, but with a significant difference in quality when compared to the samples before selection in the method using $1 \mathrm{~mL}$ of silica colloidal-PVP. Considering this, both methods can have practical application depending on the selectivity and recovery necessary in each reproductive biotechnology.

Comparative studies between colloidal silica coated with silane or PVP are necessary, employing other in vitro and in vivo fertility parameters with the objective of confirming the efficiency of fecundation of the selection methods suggested in this study. 


\section{REFERENCES}

ALVAREZ, O.G.; MAROTO-MORALES, A.; RÁMON, M. et al. Analysis of selected sperm by density gradient centrifugation might aid in the estimation of in vivo fertility of thawed ram spermatozoa. Theriogenology, v.74, p.979-988, 2010.

ANJA, S.; LOVE, C.; BALL, B.A. Use of a Single-layer density centrifugation method enhances sperm quality in cryopreserved-thawed equine spermatozoa. J. Equine Vet. Sci., v.33, p.547-551, 2013.

BUCCI, D.; SPINACI, M.; MORRE, J. et al. Effects of single layer centrifugation with Androcoll-P on boar sperm. Anim. Reprod. Sci., v.138, p.276-281, 2013.

CARVAJAL, G.; CUELLO, C.; RUIZ, M. et al. Effects of centrifugation before freezing on boar sperm cryosurvival. J. Androl., v.25, p.389-396, 2004.

DORADO, J.; ALCARÁZ, L.; DUARTE, N. et al. Changes in the structures of motile sperm subpopulations in dog spermatozoa after both cryopreservation and centrifugation on PureSperm $^{\circledR}$ gradiente. Anim. Reprod. Sci., v.125, p.211-218, 2011.

DORADO, J.; ALCARAZ, L.; GÁLVEZ, et al. Single-layer centrifugation through PureSperm ${ }^{\circledR}$ 80 selects improved quality spermatozoa from frozen-thawed dog sêmen. Anim. Reprod. Sci., v.140, p.232-240, 2013.

FALLEIROS, M.B.; BICUDO, S.D.; RODELLO, L. et al. Implications of the use of extract LDL (low density lipoprotein) or the egg yolk "purified" on motility and morphology in ovine semen cooled to 24 or 28 hours. Vet. Zootec., v.20, p.307-317, 2013.

GIL， J.; SODERQUIST, L.; RODRIGUEZMARTINEZ, H. Influence of centrifugation and diferente extenders on post-thaw sperm quality of ram sêmen. Theriogenology, v.54, p.93-108, 2000.

GUTIÉRREZ-CEPEDA, L.; FERNÁNDEZ, A.; CRESPO, F. et al. Simple and economic colloidal centrifugation protocols may be incorporated into the clinical equine sperm processing procedure. Anim. Reprod. Sci., v.124, p.85-89, 2011.
HISHINUMA, M.E.; SEKINE, J. Separation of canine epididymal spermatozoa by percoll gradient centrifugation. Theriogenology, v.61, p.365-372, 2004.

JIMÉNEZ-RABADAN， P.; MORREL，J.M.; JOHANNISSON, A. et al. Single layer centrifugation (SLC) improves sperm quality of cryopreserved Blanca-Celtiberica buck semen. Anim. Reprod. Sci., v.136, p.47-54, 2012.

MACHADO, G.M.; CARVALHO, J.O; SIQUEIRA FILHO, E. et al. Effect of percoll volume, duration and force of centrifugation, on in vitro production and sex ratio of bovine embryos. Theriogenology, v.71, p.1289-1297, 2009.

MAIA, M.S.; BICUDO, S.D. Radicais livres, antioxidantes e função espermática em mamíferos: uma revisão. Rev. Bras. Reprod. Anim., v.33, p.183-193, 2009.

MAIA, M.S.; BICUDO, S.D.; SICHERLE, C.C. et al. Lipid peroxidation and generation of hydrogen peroxide in frozen-thawed ram semen cryopreserved in extenders with antioxidants. Anim. Reprod. Sci., v.122, p.118-123, 2010.

MAKKAR, G.; HUNG-YU, N.G.; YEUNG, S.B.; HO, P.C. Comparison of two colloidal silica-based sperm separation media with a nonsilica-based médium. Fertil. Steril., v.72, p.796802, 1999.

MARTÍ, E; PÉREZ-PÉ, R.; MUIÑO-BLANCO, T.; CEBRIÁN-PEREZ, J.A. Comparative study of four different sperm washing methods using apoptotic markers in ram spermatozoa. $J$. Androl., v.27, p.746-753, 2006.

MARTINEZ-ALBORCIA, M.J.; MORREL, J.M.; GIL, M.A. et al. Suitability and effectiveness of single layer centrifugationusing Androcoll-P in the cryopreservation protocol for boar spermatozoa. Anim. Reprod. Sci., v.140, p.173-179, 2013.

MARTINEZ-ALBORCIA, M.J.; MORREL, J.M.; PARRILLA, I. et al. Improvement of boar sperm cryosurvival by using single-layer colloid centrifugation prior freezing. Theriogenology, v.78, p.1117-1125, 2012. 
MEHMOOD, A.; ANWAR, M.; SAQLAN NAQVI, S.M. Motility, acrosome integrity, membrane integrity and oocyte cleavage rate of sperm separated by swim-up or Percoll gradient method from frozen-thawed buffalo sêmen. Anim. Reprod. Sci., v.111, p.141-148, 2009.

MENDES, J.O.B.; BURNS, P.D.; TORRESANCHEZ, J.F.; SIDEL JR, G.E. Effect of heparin on cleavage rates and embryo production with four bovine sperm preparation protocols. Theriogenology, v.60, p.331-340, 2003.

MORREL, J.M.; WINBLAD, C.; GEORGAKAS, A. et al. Reactive oxygen species in stallion semen can be affected by season and colloid centrifugation. Anim. Reprod. Sci., v.140, p.62-69, 2013.

MORTIMER, S.T.E.; MAXWEL, W.M.C. Kinematic definition of ram sperm hyperactivation. Reprod. Fertl. Dev., v.11, p.2530, 1999

PEREZ, S.M.; CHAN, P.J.; PATTON, W.C.; KING, A. Silane-coated silica particle colloid processing of human sperm. J. Assist. Reprod. Genet., v.14, p.388-393, 1997.

RHO, G.J.; HAHNEL, A.C.; BETTERIDGE, K.J. Comparisons of oocyte maturation times and of three methods of sperm preparation for their effects on the production of goat embryos in vitro. Theriogenology, v.56, p.503-516, 2001.
RODELLO, L.; BICUDO, S.D.; FALLEIROS, M.B. et al. Implications of reduction in concentration of egg yolk in the extender glycine-yolk-milk on the kinetics, morphology and spermatozoa membranes integrity in semen cryopreserved ovine. Vet. Zootec., v.18, p.23924, 2011.

SAMARDZIJA, M.; KARADJOLE, M.; MATKOVIC, M. et al. A comparison of BoviPure ${ }^{\circledR}$ and Percoll ${ }^{\circledR}$ on bull sperm separation protocols for IVF. Anim. Reprod. Sci., v.91, p.237-247, 2006.

SIRCHELE C.C.; MAIA, M.S.; BICUDO, S.D. et al. Lipid peroxidation and generation of hydrogen peroxide in frozen-thawed ram semen supplemented with catalase or Trolox. Small Rum. Research, v.95, p.144-149, 2011.

SJUNNESSON, Y.C.; MORREL, J.M.; GONZÁLEZ, R. Single layer centrifugationselected boar spermatozoa are capable of fertilization in vitro. Acta Vet. Scand., v.55, p.25, 2013.

THYS, M.; VANDAELE, L.; MORREL, J.M. et al. In vitro fertilizing capacity of frozen-thawed bull spermatozoa selected by single-layer (glycidoxypropyltrimethoxysilane) silane-coated silica colloidal centrifugation. Reprod. Domest. Anim., v.44, p.390-394, 2009. 